\title{
The Effect of Fermented Corncob Feed on Daily Weight Gains and Body Condition Score on Donggala Cattle in Central Sulawesi
}

\author{
Fery Fahruddin Munier ${ }^{1, *}$, Wardi Wardi ${ }^{2}$ and Mohammad Takdir ${ }^{2}$ \\ ${ }^{1}$ Indonesian Center for Agricultural Technology Assessment and Development, Bogor \\ ${ }^{2}$ Central Sulawesi Assessment Institute for Agricultural Technology \\ *Corresponding author.Email:.ffmunier@yahoo.com
}

\begin{abstract}
The research was conducted at the Mosampora farmer group, Toaya Village, Donggala Regency, Central Sulawesi Province. The study aimed to determine the effect of fermented corncob feed on body weight gain and BCS in Donggala cattle raised in smallholder farms in Central Sulawesi. Environmental conditions during the study obtained house temperatures ranging from $30-33^{\circ} \mathrm{C}$. Twelve cows local Donggala cattle (estimated age was $24-36$ months) were used. The research design used a completely randomized design (CRD) with corn cobs treatment of $28 \%$ (T1), $30.5 \%$ (T2), and $31 \%$ (T3) with four replications. Feed was given twice a day at 08.00 am and $04.00 \mathrm{pm}$. The use of fermented corncob feed was proven to increase the daily weight gain of cattle by $0.75 \pm 0.02 \mathrm{~kg} / \mathrm{head} / \mathrm{day}$. Treatment of cornmeal in the ration had a significant effect $(\mathrm{P}<0.05)$ to increase the body weight of local cattle. The results of the study show that for BCS treatment T3 with an average increase of 50\% and T2 35\% compared to T1. The BCS's increase in intensive and semi-intensive maintenance is due to an improvement in the feed ration formula, which is calculated and adjusted to the cattle needs.
\end{abstract}

Keywords: Corncobs, donggala cattle, fermented feed,

\section{INTRODUCTION}

The root of the problem in the cattle rearing system at the level of smallholder farmers in Central Sulawesi is the pattern of traditional rearing, housing, and management of mating appropriately managed. The cattle-agricultural integrated system utilizing agricultural waste as a source of local feed has not been carried out optimally. Donggala cattle are a local breed of cattle in Central Sulawesi and have been designated as one of the national cattle families through the Decree of the Minister of Agriculture Republic of Indonesia Number: 666/kpts/SR.120/6/2014 [1]. Donggala cattle have long been kept in Donggala and Sigi, which smallholder farmers manage. Local livestock resources are potentials that need serious attention related to handling, excellent and sustainable management.

Identification of local material sources for complete feed preparation that will be applied at the study site. The survey and identification results show some feedstuffs such as coconut cake, rice bran, fish meal and, corn cobs around the study site. The availability of local feed ingredients in a sustainable manner in the area around the study site will provide its advantages because these ingredients can be formulated into quality complete feed and lower price. Thus the local cattle breeding business does not always depend on expensive commercial feed. In addition, there is a lot of corncob waste that is not utilized in Toaya village and its surroundings. Therefore processing corncobs into fermented feed is one way to utilize agricultural waste.

This effort needs to be supported by various parties by optimally utilizing local resources (comparative advantage) and applying innovative technology (competitive advantage) and other innovation to provide significant benefits for farmers. The potential of agricultural waste in the form of corn cobs which is abundant and has not been utilized becomes an opportunity to be used as potential feed. The utilization of feed fermentation technology is a method to increase 
its palatability and nutritional value. In this regard, the development of fermented feed made from corn cobs on smallholder farms in Central Sulawesi needs to be done. Therefore, this study determines the impact of daily weight changes and BCS of Donggala cattle by feeding fermented corn cobs.

\section{MATERIAL AND METHODS}

\subsection{Material}

The research was held in the Mosampora Farmers Group, Donggala Regency, Central Sulawesi Province, from January to December 2020. Dongala cattle were adapted to feed (preliminary) for two weeks before being given treatment. Preparation for its maintenance includes cleaning the cattle pen, preparing feed, and selecting cattle. Twelve Dongala cows (24-36 months) of smallholder farmers were used. Cattles were given concentrate feed and corn cond with different concentrations.

\subsection{Methods}

The research used a completely randomized design (CRD), three treatments with four replications, so there are 12 treatments. Application of local feed has been carried out pre-initial research by feeding fermented feed based on corn cobs for 14 days. Concentrate feed given $2.5 \%$ of body weight. The ration preparation was based on the cattle breeder's needs, and by preparing local feedstuff, it can be seen in Table 1. Nutritional requirements of feed calculation refer to the guidelines for the nutrient requirements of cattle. Feed was given twice a day at 08.00 am and $04.00 \mathrm{pm}$. Drinking water provided ad libitum.

The observed variables consisted of weight gain. Weighing was done every week during the treatment. The recording of body condition score on a scale of 1-5. Observation of environmental included air temperature and humidity at the location of the Mosampora group, Toaya Village, Donggala Regency. The chemical composition of feed corncob fermentation was analyzed using proximate analysis method AOAC [2] and Van soest [3].

The data were analyzed following a completely randomized design one-way analysis of variance [4]. The differences between treatments were further tested with Duncan Multiple Range Test (DMRT). Analyzed by analysis of variance using SPSS (Windows version of SPSS, release 23).

Table 1. The Feed composition ration treatment from formula corncob fermentation.

\begin{tabular}{|l|l|l|l|l|}
\hline \multirow{2}{*}{ No } & \multirow{2}{*}{ Feed Ingredients } & \% of ration & T3 \\
\cline { 3 - 5 } & & $\mathrm{T} 1$ & 58 & 60 \\
\hline 1 & Rice bran & 65 & 30.5 & 31 \\
\hline 2 & Corn cob & 28 & 1.5 & 1.5 \\
\hline 3 & Fish meal & 1.5 & 7.5 & 5 \\
\hline 4 & Kopra meal & 2.5 & 1 & 1 \\
\hline 5 & Molasses & 1.5 & 1 & 1 \\
\hline 6 & Starbio & 1 & 0.5 & 0.5 \\
\hline 7 & Urea & 0.5 & 100 & 100 \\
\hline Total & & 100 & \\
\hline
\end{tabular}

Table 2. The Chemical composition (\%) of of feed corncob fermentation (dry matter basis).

\begin{tabular}{|l|l|l|l|}
\hline \multirow{2}{*}{ Nutrient (\%) } & The treamet & T3 \\
\cline { 2 - 4 } & T1 & T2 & 93.31 \\
\hline Dry matter (DM) & 93.62 & 94.89 & 85.03 \\
\hline Organic matter (OM) & 85.39 & 85.10 & 10.74 \\
\hline Crude protein (CP) & 10.61 & 8.82 & 33.43 \\
\hline Crude fiber (CF) & 30.34 & 32.78 & 3.94 \\
\hline Ether extraction (EE) & 3.7 & 2.8 & \\
\hline
\end{tabular}

Table 3. Effect of corncob fermented used as basal feed on donggala cattle.

\begin{tabular}{|l|l|l|l|}
\hline \multirow{2}{*}{ Indicator } & \multicolumn{2}{|l|}{ The treament } & T3 \\
\cline { 2 - 4 } & T1 & T2 & $26.50^{\mathrm{b}} \pm 0.57$ \\
\hline Body weight gain & $21.75^{\mathrm{a}} \pm 0.50$ & $22.75^{\mathrm{a}} \pm 1.70$ & $0.75^{\mathrm{b}} \pm 0.02$ \\
\hline Average daily gain & $0.62^{\mathrm{a}} \pm 0.02$ & $0.65^{\mathrm{a}} \pm 0.41$ & $0.75^{\mathrm{b}} \pm 0.19$ \\
\hline Body Condition Scoring & $0.40^{\mathrm{a}} \pm 0.10$ & $0.70^{\mathrm{b}} \pm 0.08$ & \\
\hline
\end{tabular}

$\mathrm{a}, \mathrm{b}$ different superscriptions on the same line indicate significant differences $(\mathrm{P}<0.05)$ 


\section{RESULT AND DISCUSSION}

\subsection{Research site conditions}

The results of observations of environmental microclimate conditions in the Mosampora livestock group, Toaya Village, Donggala Regency. The environmental conditions during the study from 07.30 and 17.30 middle Indonesian time obtained cage temperatures ranging from $29-32^{\circ} \mathrm{C}$. This condition is according to the climate type in Central Sulawesi, which is tropical humid, and hot with an average air temperature of $29^{\circ} \mathrm{C}$ and a maximum of $33^{\circ} \mathrm{C}$.

\subsection{Corncob based fermented feed innovation}

Table 2 showed that the nutrient content for all treatments was not different, but for treatment 3, the crude protein composition was higher than $\mathrm{T} 1$ and $\mathrm{T} 2$ because the feed composition is between $0 \%-2 \%$ of the corncob composition. The final Crude protein were $\mathrm{T} 1$ $10.61 \%$, T2 $8.82 \%$, and T3 $10.74 \%$. This result is higher than the study fermentation of corn cob and tumpi-based feed using local microorganisms of crude protein ranging from $3.59 \%-4.01 \%$ [5].

The results of feed fermentation using different corn cobs gave almost the same effect on Dry matter, Organic matter, Crude protein, Crude fiber, and Crude fat compared to commercial biostarters. In contrast to the results [6], fermentation using EM4 has a significantly different effect on BETA-N and TDN (total digestible energy) in fermentation for three days. The longer the fermentation time, the better the nutritional quality of the feed, namely the higher crude protein content and the lower crude fiber. The results of field observations related to body weight of local cattle before and after application can be seen in Graph 1.

The graph 1 shows that all treatments increased the final weight of local Donggala cattle. The best treatment $\mathrm{T} 3$ increased by $22 \%$ compared to $\mathrm{T} 1$, while $\mathrm{T} 2$ only increased 5\% compared to T1. Table 3 was showed that there is a significant effect on the treatment of fermented feed on local Donggala cattle. The results showed that fermented corn cobs feed in the ration had a significant effect $(\mathrm{P}<0.05)$ on the final body weight gain of local Donggala cattle. The results showed that the addition of corn cobs (T1 and T2) was not significantly different, while T3 significantly affected final body weight gain in local Donggala cattle, and the increasing average daily gain of local cattle reached $0.75 \pm 0.02 \mathrm{~kg} / \mathrm{head} / \mathrm{day}$. This increase is in line with the previous study [7] that increase of Bali cattle ADG was caused by high protein consumption, which was $0.71 \mathrm{~kg} / \mathrm{head} /$ day to 0.98 $\mathrm{kg} / \mathrm{head} /$ day and [8] for PO cattle with ADG 0.57-0.69 $\mathrm{kg} /$ head/day The feeding forage and fermented rice straw combined with rice bran and probiotics can increase the productivity of Bali cattle [9]. However, in research [10], that basal diet with fermented corncob for $15 \%$ and $30 \%$ on the Bali Cattle feedlot were no significant effect on

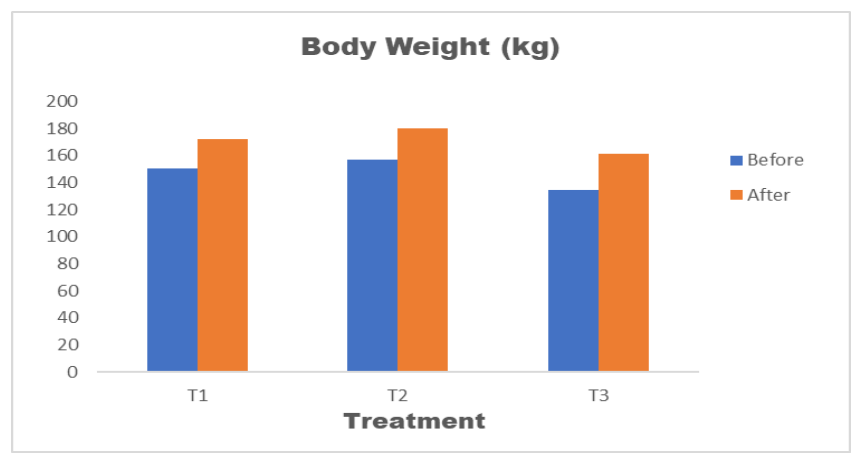

Figure 1. Graph of body weight on corncob fermented feed treatment

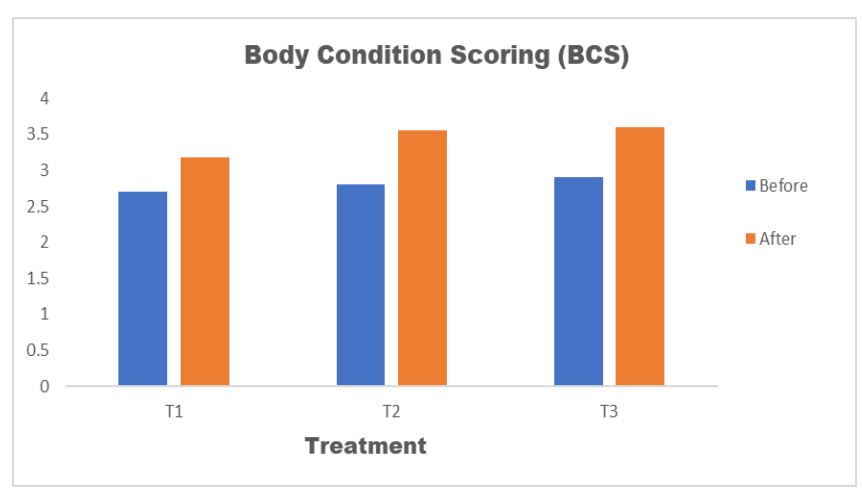

Figure 2. Graph of body condition scoring (BCS) on corncob fermented feed treatment 
performance and carcass profiles [11]. The results of field observations related to body conditions scoring of local cattle before and after application can be seen in graph 2 . The results of statistical analysis showed that fermented corncob feed had a significant effect $(\mathrm{P}<0.05)$ on the increase in BCS of Donggala cattle. Graph 2 shows that BCS of T3 treatment with an average increase of 50\% and $\mathrm{T} 2$ of 35\% compared to T1. Body Condition Scoring (BCS) is also used to observe changes in livestock's body shape as one of the factors influencing the provision of additional feed to livestock [12]. That BCS reflects the animal's recent nutritional history, and is an indicator of its future productivity. BCS is a practical way of monitoring livestock performance and it will help owners to recognize when animals fail to meet required growth paths and thus help them to achieve desired levels of productivity. Observation of BCS data was one of the factors that show the effectiveness of additional feed for livestock [13] that Body condition scoring should be used to achieve optimal body condition of the cow at calving. This will maximize the overall reproductive and economic efficiency of the herd. This is in line with the previous study that feeds improvement in cattle can positively increase the BCS value [14].

\section{CONCLUSION}

The use of fermented corncob feed with a percentage of use as much as $31 \%$ of the total ratio was proven to increase cattle body weight and improve BCS.

\section{REFERENCES}

[1] Decree of the Minister of Agriculture republic of Indonesia for Donggala cattle are a local breed, number: 666/kpts/SR.120/6/2014, Jakarta, 2014.

[2] AOAC, Official methods of analysis. Assoc. Off. Ana. Chem, Washington DC (US), 2005.

[3] A.D. Tillman, H. Hartadi, S. Reksohadiprodjo, S. Prawirokusomo and S. Lebdosoekojo, Ilmu makanan ternak dasar. Gadjah Mada University, Yogyakarta, 1983.

[4] M. Astuti, Experimental design and statistical analysis. UGM Press, 1980.

[5] H. Khasanah., L. Purnamasari, and D. E. Kusbianto, Utilization of MOL (Local Microorganisms) as Substitute for EM4 Biostarter to Improve Nutritional Quality of Corncob-Based Fermented Feed and Corn Tumpi, 2020, Prosiding Seminar Nasional Teknologi Peternakan dan Veteriner.

[6] E. Mirwandono, M. Sitepu, T.H. Wahyuni, Hasnudi, N. Ginting, G.A.W. Siregar, I. Sembiring, Nutrition quality test of fermented waste vegetables by bioactivator local microorganisms (MOL) and effective microorganism (EM4), 2018, IOP
Conference Series: Earth and Environmental Science. p. 122.

[7] M.L. Lani, L. Abdullah and R. Priyanto, Utilization of Leucaena leucocephala in traditional fattening program of Bali cattle in Amarasi, 2015, Media Peternakan, 38(1), pp.64-69.

[8] N. Ngadiyono., E. baliarti., T.S.M. Widi., H. Maulana and B.A. Atmoko. 2019. Effect of breed and initial body weight on daily weight gain of Simmental Ongole Crossbred cattle and ongole Grade cattle. IOP Conf. Series: Earth Environ. Sci. 387: 012044.

[9] I.N. Sugama and N.L.G. Budiari, Utilization of rice straw as an alternative feed for bali heifers, 2012, Majalah Ilmiah Peternakan, 15(1), p.164345.

[10] N.L.P. Sriyani, W. Siti, G. Suarta, I.B.G. Partama, N.T. Ariana and W.S. Yupardhi, Responses of corncob as replacement of elephant grass on performance and carcass profile of Bali cattle, 2018, International Journal of Life Sciences, 2(1), pp.4249.

[11] Y. Wairato, M. Yunus and G.A.Y. Lestari, Nutrient intake of bali cattle fattened with local farmers' kept pattern and fed concentrate containing fermented corncob meal, 2019, Jurnal Peternakan Lahan Kering, 1(4), 579-588.

[12] F.S. Soares and G. Dryden, A Body Condition Scoring System for Bali Cattle, 2011 Asian-Aust. J. Anim. Sci. Vol. 24, No. 11: 1587 - 1594.

[13] A.M. Encinias and G. Lardy, Body condition scoring I: Managing your cow herd through body condition scoring, 2000.

[14] B.N. Utomo and W. Ermin, Development of beef cattle based on oil palm plantation industry, 2012, J. Litbang Pert. Vol. 31 No. 4 Desember 2012: 153161. 